\title{
Learning Organizations and Innovation Mediated by Job Satisfaction
}

\author{
Rania Abdel Razzaq Allouzi, Taghrid Saleh Suifan*, Mohammed Alnuaimi \\ Department of Business Management, the University of Jordan, Amman, Jordan \\ Email address: \\ t.suifan@ju.edu.jo (T. S. Suifan) \\ ${ }^{*}$ Corresponding author \\ To cite this article: \\ Rania Abdel Razzaq Allouzi, Taghrid Saleh Suifan, Mohammed Alnuaimi. Learning Organizations and Innovation Mediated by Job \\ Satisfaction. International Journal of Business and Economics Research. Vol. 7, No. 1, 2018, pp. 7-19. doi: 10.11648/j.ijber.20180701.12
}

Received: February 2, 2018; Accepted: February 25, 2018; Published: March 20, 2018

\begin{abstract}
The purpose of this research is to investigate whether job satisfaction plays a mediating role in the relationship between learning organization and organizational innovation. To perform this research, questionnaires were used to collect data from 20 insurance companies in Jordan listed on the Amman Stock Exchange. Data were analyzed using the Statistical Package for Social Sciences, with descriptive analysis used to obtain general information about the employees and linear regression analysis used to test the research hypotheses. The results of this research indicate that learning organization positively impacts job satisfaction, that job satisfaction has a significant impact on organizational innovation, and that learning organization has a significant impact on organizational innovation. Further, job satisfaction was found to play a mediating role in the relationship between learning organization and organizational innovation. This research's findings suggest that insurance companies that operate as learning organizations and seek improvements in their innovativeness should take employee job satisfaction into account. This research is important for companies seeking to improve the innovativeness of their employees. It shows that this can be encouraged by becoming a learning organization and concurrently improving employees' job satisfaction.
\end{abstract}

Keywords: Learning Organization, Job Satisfaction, Mediating Impact, Organizational Innovation, Insurance Companies

\section{Introduction}

Today, organizations are operating in complex, dynamic, and competitive environments [1]; they are regularly confronted by challenges related to the impact of globalization, technology, and economic factors, and this has created a need for innovative solutions [2].

In particular, knowledge-intensive organizations rely heavily on innovation for their survival [3]. It has consequently been found that knowledge-promoting environments increase the innovative prospects of employees, and, as a result, establishing such environments has become a priority for all organizations [4].

The significance of fostering a learning organization was first recognized in 1965 [5]. However, over the past two decades there has been a huge increase in interest in learning within organizations [6], mainly based on the belief that innovation and learning are critical for organizations' survival in dynamic environments [7]. Innovation is a critical capability for organizations, since success through the creation of novel goods is a source of growth, and this can also result in increased sales, profits, and a competitive advantage [8-9]. However, to remain competitive, organizations must constantly adapt and change through implementing comprehensive learning procedures [10]. Learning organizations are better able to detect opportunities and recognize trends in the surrounding environment than their competitors, which results in greater products/services and performance [11]. However, competitive organizations also rely on the support and contributions of their employees [12] Therefore, maintaining employee job satisfaction is essential for organization's success, competitiveness, and effectiveness [13].

There are many distinctions between past and present-day organizations; however, one of the primary features of today's organizations is that their formulation is based on learning [14]. Depending on the dynamic nature of work, 
organizations should consider learning as more critical factor than it could have been before [2]. However, the capability of employees and organizations to learn is seen as a primary source of success [10]. Reference [15] defined innovation as a form of learning; thus, organizations can obtain the benefits of innovation through implementing learning processes [16].

Since learning organizations promote learning internally, they positively impact organizational innovation [17]. This argument is supported by [18], which states that an effective learning organization develops the capability to innovatethat is, the organization's ability to successfully utilize new thoughts, procedures, or products. However, according to [19], there is a lack of literature concerning the impact learning organization has on organizational innovation and performance; moreover, although there is a great deal of research concerning learning organization and employees' efforts to implement innovative behaviors, additional investigation from different perspectives is required in this regard [20].

Further, despite the importance of the relationship between learning organization and organizational innovation, there is also a gap in the literature regarding the mediating role job satisfaction plays in this relationship [19-20]. Many researchers have concluded that learning organizations are associated with a positive and significant influence on job satisfaction [21-23]. Moreover, other researchers have concluded that job satisfaction in turn has a positive and significant impact on organizational innovation [24-25]; however, this is disputed by [26], which found a negative and insignificant relationship between job satisfaction and organizational innovation.

Considering the above, the goal of this research was to investigate whether job satisfaction plays a mediating role in the relationship between learning organization and organizational innovation. To determine this, a number of insurance companies in Jordan were examined. Such companies were particularly suitable for this research because the insurance sector is operating in a dynamic and complex environment [27], and companies are constantly forced to adjust to the frequent environmental changes that occur [28]. Further, many related studies have recommended that investigations into learning organization in sectors such as insurance, banking, and education be conducted [17, 2930].

\section{Literature Review}

\subsection{Learning Organization}

Learning organization is not a new concept; it has existed since approximately the early twentieth century. However, it has recently attracted great interest, mainly because the environments in which present-day organizations operate have become more dynamic and sophisticated [2]. The significance and magnitude of learning organization has been extensively debated in previous literature [31]; however, despite such discussions, a clear definition of learning organization has not yet been determined [32].

The concept of learning organization is more related to developing countries; since it assists in improving the efficiency of its individuals' skills, knowledge, and their capabilities for decision-making [2]. A learning organization is defined as an organization that continually shares knowledge about markets, products, technologies, and business procedures [33]. Learning organizations can also be defined as organizations that encourage all of their employees to learn, and which continually modify themselves [34]. Thus, learning organizations are skillful at generating, obtaining, and transferring knowledge, as well as adjusting their activities to reflect newly acquired knowledge [35]. Moreover, learning organizations can be viewed as institutions in which knowledge is comprehensively applied, business capacity is developed, and competence is obtained [36]. Considering this, the main definition of a learning organization is an organization that has the capability to promote innovation and to continuously evolve [37].

According to many researchers, learning organization involves three levels: individual, team, and organizational. Individual-level learning relates to the abilities that individuals are born with and which cannot be taught [38]. Meanwhile, learning at the team level relates to individuals who work together, share information, and consider mistakes to be opportunities to learn [32]. Finally, learning at the organizational level concerns a learning procedure implemented within organizations that is based on the interaction of employees, and which leads to the attainment of an organization's objectives [39].

Learning organization is considered to be a key method of managing an organization, as in this format the management and development of employees are basic pillars, and commitment, team work, delegation, confidence, and employee involvement in the organization are emphasized [40]. In essence, learning organization empowers and supports employees to learn by providing them with resources and rewards [30].

In learning organizations, top management is not depended upon to assign tasks; instead, various resources and talented employees contribute to attaining overall goals. In particular, successful learning organizations utilize creative approaches to address unique issues [41].

Reference [14] studied learning organizations based on Senge's learning-organization principles [42]: personal mastery (relating to individuals' opinions, which become continuously informed in such environments [43]), mental models (the perception of the world and the way it works [44]), building a shared vision (creating a common future image for the organization [45]), team learning (a learning procedure in which team members develop collective knowledge, perceptions, and competence to perform tasks and to address problems in daily work [46]), and systems thinking (the core of learning organization, since it merges all dimensions with the aim of improving the organization [29]). Similarly, in this research, Seng's dimensions of learning organization were chosen as a base for measuring learning 
organization [47].

\subsection{Job Satisfaction}

The concept of job satisfaction has always been a prime study topic in the domain of organizational behavior, and it is generally defined as an individual's feelings and attitudes toward his/her job [48].

Reference [49] defined job satisfaction as a function of the perceived relationship between that which an employee needs from his/her job and that which he/she perceives it to be offering [50]. Thus, job satisfaction is an employee's emotional reaction to the perceived value he or she obtains from his or her job, and if the employee perceives this value to be satisfactory, he/she is satisfied [51].

Job satisfaction is regarded as an important work outcome existing at the core of individual and organizational wellbeing [52], and it is a critical factor influencing organizational performance, effectiveness, and competitiveness $[23,53]$. Job satisfaction also has an impact on employee's commitment, productivity, absenteeism, and performance [54]. Employees' job satisfaction can be increased through ensuring fair performance evaluations and reward systems [50].

According to [55], job satisfaction comprises two dimensions: personal and organizational factors. Personal factors include age, gender, religion, and race, while organizational factors include leadership, organizational change, and technological innovation.

Further, many researchers have studied the concept of job satisfaction in terms of Herzberg's two-factors theory [56], which is one of the earliest theories to have stated that job satisfaction includes both intrinsic and extrinsic job elements [25, 51, 57-59]. According to [56], intrinsic job satisfaction factors are motivating factors, and their presence leads to satisfied individuals, while extrinsic job satisfaction factors, or hygiene factors, are not necessarily satisfying, but their absence might cause dissatisfaction [59].

\subsection{Organizational Innovation}

The concept of innovation has been studied by people such as Adam Smith and Alfred Marshall, along with many other scientists; these researchers have examined the influence innovation has on goods and methods, as well as its economic significance [60]. Today, innovation and continuous development are critical factors that help organizations improve their competitive advantage [61]. In fact, organizational innovativeness is a sophisticated phenomenon, and it is not easy for most organizations to attain successful innovation [6]. Organizations mainly require innovation to adapt to changes in their external environments [62], and organizations that possess high innovation capacities are capable of adapting to environmental challenges faster, of developing more novel products, and of detecting market opportunities more efficiently than noninnovative organizations [63]. The introduction of new goods/services and procedures into an organization allows the organization to simplify its responses to changes in its complex environment [64].

Organizations must utilize knowledge, capabilities, competences, opportunities, and their employees' desires to innovate and achieve better innovation [65]. According to [66], innovation has many forms, such as revolutionary and evolutionary innovation, product and procedure innovation, and managerial and technical innovation. Further, innovation has been defined as the bringing of new thoughts, goods, services, equipment, or procedures into an organization [67]. It has also been defined as the achievement of novel results and outcomes through the implementation of new ideas and techniques [68]. Innovation can only occur if an organization has innovative capabilities relating to available resources, cooperative mechanisms, and problem-solving procedures [69]. Specifically, organizational innovation is defined as the adoption of new knowledge approaches for performing management jobs and of novel procedures that change organizations' frameworks, strategies, processes, and systems [70]. It has also been defined as innovation that involves new administrative procedures, new marketing concepts, new strategies, and new organization [71].

Innovation can be measured using various methods [72], such as examining market performance, product innovation, technological innovation, and market innovation [73, 74]. In addition, researchers who wish to measure organizational innovation utilize process innovation, structural innovation, and competence innovation as measurements [73-75].

According to [67], organizational innovation includes three dimensions: knowledge management systems, work organization, and external relations. However, the model proposed by [76] for organizational innovation consists of five dimensions: product innovation, market innovation, process innovation, behavioral innovation, and strategic innovation. In another variation, reported by [77, 69], organizational innovation can be classified into three main dimensions: product, process, and management innovation. Considering the above, for this research the latter three dimensions were chosen to measure organizational innovation in the service sector. This was because these dimensions have previously been used to measure organizational innovation in the service sector $[69,78]$.

\section{Research Model and Development of Hypotheses}

In this research, job satisfaction is hypothesized to mediate the relationship between learning organization and organizational innovation. Further, it is hypothesized that learning organization has a positive impact on both job satisfaction and organizational innovation, and that job satisfaction has a positive impact on organizational innovation. From the above literature review, it is clear that learning organization affects job satisfaction [16] and that it also enhances organizational innovation [19]. Consequently, this research argues that insurance companies that operate as 
learning organizations improve their employees' job satisfaction, which in turn enhances the innovativeness of the

companies. The proposed research model is presented in Figure 1.

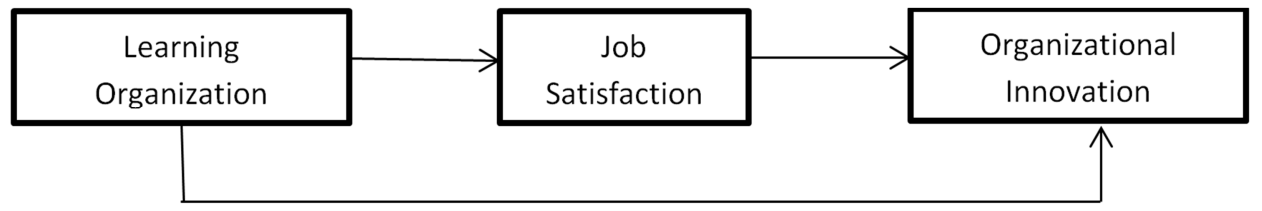

Figure 1. Research model.

\subsection{Learning Organization and Job Satisfaction}

Reference [79] found that learning organization is related to enhanced job satisfaction; by promoting continuous learning and systems thinking, it is possible to modify employees' thoughts and judgments concerning their jobs and increase their satisfaction levels. Learning organization plays a significant role in improving employees' skills and attitudes, and is also capable of reducing problems relating to job rotation [21]. Furthermore, enhancing employees' thoughts about values and empowering them can actually improve their job willing and increase their external satisfaction [23]. Satisfied employees are stimulated to confront unfamiliar challenges and have greater commitment to their organizations, which eventually leads to improvements in organizational effectiveness [80].

Since learning organization has a significant impact on job satisfaction, it can be considered an effective strategy for retaining employees and helping them to be creative in terms of addressing changes [47]. Many researchers have investigated the relationship between learning organization and job satisfaction, finding it to be significant and positive, and these researches cleared that the implementation of learning organization will end-up in increasing employees' job satisfaction, thus at the end will improve the profit growth of the organization [16, 22-23].

H1. Learning organization has a significant impact on job satisfaction.

\subsection{Learning Organization and Organizational Innovation}

Several valued outcomes for organizations-such as innovativeness, effectiveness, better fit with the surrounding environment, and possessing a competitive advantage-are related to learning organization [11]. Further, learning organizations have the ability to maintain or enhance performance, especially in the long term [81]. Becoming a learning organization can help companies adapt to the dynamic environments that they operate in and also to preserve their capacity to implement sustainable improvement and development [37].

Employees working in learning organizations improve permanently, mainly as a result of such organizations' inherent structures and resources, which encourage employees to think in inventive ways and strive to achieve mutual objectives [82]. Further, as mentioned above, product/service innovation and management innovation can be predicted and improved in learning-organization settings [83], and several studies have reported that learning organization has a positive influence on organizational innovation and argues that learning organizations perform better in terms of improved products and services as well as in terms of operational and financial outcomes [17, 19-20, 81].

H2. Learning organization has a significant impact on organizational innovation.

\subsection{Job Satisfaction and Organizational Innovation}

Employees who perform more than one duty concurrently in their jobs have a great degree of satisfaction. Thus, variation and change in a job can be considered linked with innovation and creativity [84-86] since organizational innovation is affected by employees' level of job satisfaction, which means satisfied employees put extra effort and energy into their work [24]. In addition, products and services will be enhanced and organizations will have competitive advantage depending on their employees and on their satisfaction level [20].

Further, several previous studies have shown that job satisfaction is an essential aspect that causes employees to be more willing to put forth great effort; in other words, employees perform better when they are satisfied with their current jobs [87].

H3. Job satisfaction has a significant impact on organizational innovation.

\subsection{Mediating Role of Job Satisfaction in the Relationship Between Learning and Organizational Innovation}

The positive impact learning organization has on organizational innovation has been reported in many previous studies. For example, it was found that learning organization can enhance employees' job satisfaction while others found that satisfied employees positively influence organizational innovation [24, 80]. Considering such findings, this research argues that learning organization has a greater impact on organizational innovation when employees are satisfied with their jobs.

Learning organization can be seen as a strategy for retaining employees while also helping them to be creative concerning addressing challenges [47]. In addition, the reward system that is related to the implementation of learning organization will lead to improve employees' capability to deal with changes and innovation inside the organization [16]. Further, job satisfaction is considered a critical outcome of organizational well-being [52].

Although the mediating role job satisfaction plays in the 
relationship between learning organization and organizational innovation has not been discussed and examined in previous literature, this research presents the following hypothesis based on the above findings:

H4. Job satisfaction positively mediates the relationship between learning organization and organizational innovation.

\section{Methodology}

\subsection{Data Collection and Sample}

For this research, the target population was all insurance companies in Jordan listed on the Amman Stock Exchange (ASE). This sample was chosen because the environment in which insurance companies operate is dynamic and uncertain. Thus, they must become learning organizations to cope with and adjust to environmental changes that occur.

The target population consisted of 20 companies, which had a total of 2,391 employees. Based on the method used by [88], the appropriate sample size for the research population was determined to be 327 employees. Consequently, simple random sampling was employed for the extracted sample, and 327 questionnaires were distributed, of which 316 were returned. Of these, 14 were invalid; therefore, they were discarded, and the remaining 302 were used for analysis, resulting in a response rate of $92 \%$.

\subsection{Measurement Scale Assessment}

The items used to measure the research variables were adopted from previous literature. Specifically, to measure learning organization, a scale adopted from [89] was used. Job satisfaction was measured using the Minnesota Satisfaction Questionnaire, which was developed by [90], and organizational innovation was measured using the scale by [78].

As can be seen, the adopted measurement scales were related to the operational definitions of the variables employed in this research. Learning organization is defined as a group of employees working together to improve their capabilities and to provide their organization with novel ideas and knowledge [89]. Job satisfaction is defined as employees' attitudes towards their jobs [90], and organizational innovation refers to changes in the products an organization offers and the methods by which it creates and delivers those products [78].

The measurement scales were translated into Arabic to make it easier for the respondents to respond them. Each item was answered using a five-point Likert scale, through which respondents could show their level of agreement with each statement.

\subsection{Validity and Reliability}

It is important to measure the validity and reliability of all researches. According to [88], measuring both validity and reliability is critical for research to be considered robust and scientific. Thus, validity tests were employed to ensure that the instruments actually measured the specific concepts they were developed to measure.

First, content validity was considered, which confirms whether a measure's items are adequate and represent the intended concept [88]. Since the measuring instruments used in this research were sourced from a valid reliable scale that was designed and examined by several researchers, it can be considered that the measuring instruments were sufficient in this regard.

Nevertheless, determining face validity, a basic form of content validity, would be beneficial for ensuring the validity of the items used. This involved presenting the questionnaire-before distribution-to three educational experts in business administration and asking them to give their opinions concerning the used items. Their recommendations were fully considered when designing the questionnaire.

Further, construct validity was also examined. This involves examining how well results acquired through the utilization of a measurement tool fit the theories that the test is based on [88].

Next, factor analysis was conducted to test construct validity, as this is a popular method that has been used for several decades [91]. Factor analysis is a multivariate method that determines whether the dimensions of the concept in question have been operationally defined; this method is also capable of revealing the items that are most suitable for every dimension [88]. Specifically, exploratory factor analysis (EFA) was chosen as the analysis method, as this can be used to reveal and estimate the unidimensionality of the theoretical construct, develop an underlying theory, and estimate the construct validity of a scale [92]. To conduct EFA, three conditions must be met: 1) the Kaiser-Meyer-Olkin measure should be above $0.50,2$ ) the eigenvalue for each factor should be 1 or more, and 3 ) each item should have a factor loading of 0.40 or more [93]. Here, promax rotation was applied since it generates correlated factors and is widely used in research on human behavior and psychology.

The results of the EFA for learning organization are shown in Table 1. The KMO value was 0.893, which fulfills the requirement of being greater than 0.50. Bartlett's test of sphericity chi-square $\chi 2$ was statistically significant $(p \leq$ 0.00 ) for all items. The eigenvalues for all five factors exceeded 1 , and all items had loadings of over 0.40 .

Table 1. Exploratory factor analysis for learning organization.

\begin{tabular}{|c|c|c|c|}
\hline \multicolumn{2}{|c|}{ Items } & \multirow{2}{*}{$\begin{array}{l}\text { Factor } 1 \text { Team } \\
\text { Learning } \\
0.733\end{array}$} & \multirow[t]{2}{*}{$\begin{array}{l}\text { Factor } 2 \text { Systems } \\
\text { Thinking }\end{array}$} \\
\hline 1 & Cross-functional learning teams are organized on a regular basis. & & \\
\hline 2 & Teams/groups have the freedom to modify their goals and break old patterns of work, as needed. & 0.766 & \\
\hline 3 & All team members share responsibility and are treated equally. & 0.781 & \\
\hline 4 & Teams revise their thinking through group discussions. & 0.709 & \\
\hline
\end{tabular}




\begin{tabular}{lll}
\hline Items & $\begin{array}{l}\text { Factor 1 Team } \\
\text { Learning }\end{array}$ & $\begin{array}{l}\text { Factor 2 Systems } \\
\text { Thinking }\end{array}$ \\
\hline 5 & Teams are recognized and rewarded for their achievements as a team/group. & 0.726 \\
6 & Teams are confident that the company will act on their recommendations. & 0.678 \\
7 & In my company, people cooperate and help each other to learn. & 0.448 \\
8 & My company is considered to be one whole system, consisting of several integrated subsystems. & 0.822 \\
9 & Employees recognize the importance of the complementary performance of their departments. & 0.768 \\
10 & The company is perceived as one part of a larger economic and social system. & 0.688 \\
11 & My company is constantly working to create and acquire new knowledge. & \\
12 & My company considers employee learning to be one of its highest priorities. & \\
13 & Self-directing learning is expected, encouraged, and rewarded. & \\
14 & Employees at all levels identify the skills they will require for future work tasks. & \\
15 & There is a willingness to break old patterns and to experiment with different ways of managing daily work. & \\
16 & Applicable creative, innovative, and risk-taking ideas are encouraged and rewarded. & \\
17 & Employees are allowed to question current practices, rules, and strategies. & \\
18 & My company's vision and goals are clear, flexible, communicable, and attainable. & \\
19 & Employees have common future trends and visions. & \\
20 & Employees are permitted to participate in the strategic management process. & \\
Initial Eigenvalues (Total) & & 10.932 \\
Percentage of Variance & & \\
\hline
\end{tabular}

Table 1. Continued.

\begin{tabular}{|c|c|c|c|c|}
\hline \multicolumn{2}{|c|}{ Items } & \multirow[t]{2}{*}{$\begin{array}{l}\text { Factor } 3 \text { Personal } \\
\text { Mastery }\end{array}$} & \multirow[t]{2}{*}{$\begin{array}{l}\text { Factor } 4 \text { Mental } \\
\text { Models }\end{array}$} & \multirow[t]{2}{*}{$\begin{array}{l}\text { Factor } 5 \text { Building } \\
\text { Shared Vision }\end{array}$} \\
\hline 1 & Cross-functional learning teams are organized on a regular basis. & & & \\
\hline 2 & $\begin{array}{l}\text { Teams/groups have the freedom to modify their goals and break old patterns of work, } \\
\text { as needed. }\end{array}$ & & & \\
\hline 3 & All team members share responsibility and are treated equally. & & & \\
\hline 4 & Teams revise their thinking through group discussions. & & & \\
\hline 5 & Teams are recognized and rewarded for their achievements as a team/group. & & & \\
\hline 6 & Teams are confident that the company will act on their recommendations. & & & \\
\hline 7 & In my company, people cooperate and help each other to learn. & & & \\
\hline 8 & $\begin{array}{l}\text { My company is considered to be one whole system, consisting of several integrated } \\
\text { subsystems. }\end{array}$ & & & \\
\hline 9 & $\begin{array}{l}\text { Employees recognize the importance of the complementary performance of their } \\
\text { departments. }\end{array}$ & & & \\
\hline 10 & The company is perceived as one part of a larger economic and social system. & & & \\
\hline 11 & My company is constantly working to create and acquire new knowledge. & 0.733 & & \\
\hline 12 & My company considers employee learning to be one of its highest priorities. & 0.750 & & \\
\hline 13 & Self-directing learning is expected, encouraged, and rewarded. & 0.747 & & \\
\hline 14 & Employees at all levels identify the skills they will require for future work tasks. & 0.618 & & \\
\hline 15 & $\begin{array}{l}\text { There is a willingness to break old patterns and to experiment with different ways of } \\
\text { managing daily work. }\end{array}$ & & 0.674 & \\
\hline 16 & Applicable creative, innovative, and risk-taking ideas are encouraged and rewarded. & & 0.818 & \\
\hline 17 & Employees are allowed to question current practices, rules, and strategies. & & 0.770 & \\
\hline 18 & My company's vision and goals are clear, flexible, communicable, and attainable. & & & 0.671 \\
\hline 19 & Employees have common future trends and visions. & & & 0.850 \\
\hline & Employees are permitted to participate in the strategic management process. & & & 0.796 \\
\hline \multicolumn{2}{|c|}{ Initial Eigenvalues (Total) } & 1.715 & 1.337 & 1.023 \\
\hline \multicolumn{2}{|c|}{ Percentage of Variance } & 8.575 & 6.684 & 5.162 \\
\hline
\end{tabular}

Table 2 show the EFA with regard to job-satisfaction dimensions. Here, the KMO value was 0.906, which exceeds the requirement of 0.50 . Bartlett's test of sphericity chi-square $\chi^{2}$ was statistically significant $(p \leq 0.00)$ for all items. The eigenvalues for both factors exceeded 1 , and all items had loadings of over 0.40 .

Table 2. Exploratory factor analysis for job satisfaction.

\begin{tabular}{llll}
\hline Item & Factor 1 Intrinsic Job Satisfaction & Factor 2 Extrinsic Job Satisfaction \\
\hline 1 & I am able to constantly keep busy in my job. & 0.777 \\
2 & I have opportunities to work alone at a job. & 0.548 \\
3 & I have opportunities to occasionally do different things. & 0.746 \\
4 & I have opportunities to do things that don't conflict with my & 0.768 \\
& conscience. & 0.668 \\
5 & My job provides me with steady employment. & 0.793 \\
6 & I have opportunities to do things for other people. & 0.750 \\
7 & I have opportunities to do something that makes use of my abilities. & 0.617 \\
8 & I have the freedom to use my own judgment. & \\
\hline
\end{tabular}




\begin{tabular}{lll}
\hline Item & Factor 1 Intrinsic Job Satisfaction & Factor 2 Extrinsic Job Satisfaction \\
\hline 9 & I get a feeling of accomplishment from my job. & 0.664 \\
$10 \quad$ I have opportunities to try my own methods of doing my job. & 0.632 & \\
$11 \quad$ I like the way my boss handles his/her workers. & & 0.519 \\
$12 \quad$ My supervisor is competent when making decisions. & & 0.575 \\
$13 \quad$ I am satisfied with my pay and the amount of work I do. & & 0.658 \\
$14 \quad$ I like the way my co-workers get along with each other. & & 0.627 \\
$15 \quad$ I like the way company policies are put into practice. & & 0.720 \\
$16 \quad$ I have opportunities for advancement in this job. & & 0.772 \\
$17 \quad$ I like the praise I get for doing a good job. & 7.926 & 0.752 \\
$18 \quad$ I like the working conditions. & 49.535 & 0.592 \\
Initial Eigenvalues (Total) & & 1.425 \\
Percentage of Variance & 8.908 \\
\hline
\end{tabular}

Table 3 shows the EFA for organizational innovation. Here, the KMO value was 0.925 , which is greater than 0.50 . Bartlett's test of sphericity chi-square $\chi^{2}$ was statistically significant $(p \leq 0.00)$ for all items. The eigenvalues for all three factors exceeded 1 , and all items had loadings of more than 0.40 .

Table 3. Exploratory factor analysis for organizational innovation.

\begin{tabular}{|c|c|c|c|c|}
\hline Item & & $\begin{array}{l}\text { Factor 1 } \\
\text { Process } \\
\text { Innovation }\end{array}$ & $\begin{array}{l}\text { Factor } 2 \\
\text { Management } \\
\text { Innovation } \\
\end{array}$ & $\begin{array}{l}\text { Factor } 3 \\
\text { Product } \\
\text { Innovation }\end{array}$ \\
\hline 1 & $\begin{array}{l}\text { Our company consistently develops novel skills for transforming old services into new ones for the } \\
\text { market. }\end{array}$ & 0.579 & & \\
\hline 2 & Our company often tries different operation procedures to hasten the realization of the its goals. & 0.712 & & \\
\hline 3 & Our company consistently acquires new skills to improve the service process. & 0.738 & & \\
\hline 4 & Our company is capable of developing efficient operation procedures. & 0.787 & & \\
\hline 5 & Our company can flexibly provide services that meet customers' demands. & 0.820 & & \\
\hline 6 & The new operation procedures employed by our company are consistently imitated by our competitors. & 0.668 & & \\
\hline 7 & $\begin{array}{l}\text { Our company changes the division of work among different departments in accordance with market- } \\
\text { management needs. }\end{array}$ & & 0.568 & \\
\hline 8 & $\begin{array}{l}\text { Our company's department heads adopt new leadership approaches to lead all staff towards task } \\
\text { completion. }\end{array}$ & & 0.479 & \\
\hline 9 & The new staff welfare system adopted by our company can effectively provide incentives to our staff. & & 0.806 & \\
\hline 10 & $\begin{array}{l}\text { The new financial management system adopted by our company can effectively monitor the actual } \\
\text { discrepancies between our performance and our goals. }\end{array}$ & & 0.794 & \\
\hline 11 & Our company emphasizes innovative and creative capability when recruiting staff. & & 0.847 & \\
\hline 12 & The new staff recruitment system adopted by our company is efficient and effective. & & 0.826 & \\
\hline 13 & $\begin{array}{l}\text { The new performance-assessment method adopted by our company can enable department heads to } \\
\text { gain a better picture of the degree to which staff have achieved the company's goals. }\end{array}$ & & 0.752 & \\
\hline 14 & Our company often develops new services that are readily accepted by the market. & & & 0.726 \\
\hline 15 & A great majority of our company's profits are generated by the new services it has developed. & & & 0.768 \\
\hline 16 & The new services developed by our company are consistently imitated by our competitors. & & & 0.845 \\
\hline 17 & Our company often launches new services before our competitors. & & & 0.769 \\
\hline 18 & $\begin{array}{l}\text { Our company has better R\&D capabilities in regard to the creation of new services than our } \\
\text { competitors. }\end{array}$ & & & 0.674 \\
\hline \multicolumn{2}{|c|}{ Initial Eigenvalues (Total) } & 9.248 & 2.226 & 1.127 \\
\hline \multicolumn{2}{|c|}{ Percentage of Variance } & 51.375 & 12.368 & 6.263 \\
\hline
\end{tabular}

Reliability is related to the consistency of a research instrument with regard to measuring a specific variable at any time. To determine this, it is repeatedly utilized under the same situations with the same subjects [94]. In this research, Cronbach's alpha was employed to measure reliability, as this is the usual measure for determining internal consistency [95]. According to [88], Cronbach's alpha is a reliability coefficient that shows how closely certain items in a set are related to each other. Cronbach's alpha can range from 0.0 to 1.0 , with results closer to 1.0 indicating higher internal consistency [88].

Table 4 presents the Cronbach's alphas for this research. The table shows that all variables met the recommended ruleof-thumb standard of $\alpha \geq 0.70$, indicating high internal consistency [96].

\section{Results}

This section presents the results of the empirical analysis performed to test the research's hypotheses. Means, standard deviations, and reliabilities are shown in Table 4. Before testing the research hypotheses, tests were conducted to confirm the data's adequacy for verifying research's assumptions concerning the regression analysis. This involved conducting a variance inflation factor (VIF) test and examining the tolerance of each variable. Consequently, it was found that none of the VIF values exceeded the permissible value of 10 , and that all of the tolerance values were above 0.05 . 
Table 4. Means, standard deviations, and reliabilities of the research variables.

\begin{tabular}{llll}
\hline & Mean & SD & Cronbach's $\boldsymbol{\alpha}$ \\
\hline 1. Learning organization & 3.3680 & 0.67851 & 0.929 \\
2. Job satisfaction & 3.4912 & 0.72939 & 0.913 \\
3. Organizational innovation & 3.3471 & 0.73490 & 0.943 \\
\hline
\end{tabular}

Table 5. Regression results for mediation analysis.

\begin{tabular}{|c|c|c|c|c|c|}
\hline Model & $\mathbf{R}$ & $\mathbf{R}^{2}$ & Beta Estimate & SE & p-value \\
\hline \multicolumn{6}{|l|}{ Total impact of IV on DV } \\
\hline Learning organization $\rightarrow$ Organizational innovation & 0.796 & 0.634 & 0.863 & 0.038 & 0.000 \\
\hline Total impact of IV on mediator variable & & & & & 0.000 \\
\hline Total impact of the mediator variable on DV & & & & & 0.000 \\
\hline Job satisfaction $\rightarrow$ Organizational innovation & 0.761 & 0.580 & 0.767 & 0.038 & 0.000 \\
\hline Indirect impact of IV on DV through the mediator variable & & 0.680 & 0.562 & .058 & 0.000 \\
\hline
\end{tabular}

To test the hypotheses of this research, the approach used in [97] was applied, which comprises three steps. The first concerns examining the direct effect of the independent variable (IV) on the dependent variable (DV). Second, the direct effect of the independent variable on the mediator variable is examined. Third, the direct effect of the mediator variable on the dependent variable is examined. Finally, the indirect effect between the independent and dependent variables, which is mediated by the mediating variable, is computed, and this is then tested for significance using structural equation modeling (SEM).

Linear regression analysis was used to examine the direct effect of the independent variable on the dependent variable. Table 4 shows that learning organization positively impacts job satisfaction $\left(\mathrm{R}=0.793, \mathrm{R}^{2}=0.628, \beta=0.852, p\right.$-value $=$ $0.000)$; therefore, hypothesis H1 is supported. With regard to hypothesis $\mathrm{H} 2$, which states that learning organization has a significant impact on organizational innovation, the results showed that the direct impact of IV on DV is both positive and significant $\left(\mathrm{R}=0.796, \mathrm{R}^{2}=0.634, \beta=0.863, p\right.$-value $=$ 0.000); thus, hypothesis $\mathrm{H} 2$ is supported.

For hypothesis H3, which states that job satisfaction has a significant impact on organizational innovation, the results showed that job satisfaction indeed has a significant impact on organizational innovation $\left(\mathrm{R}=0.761, \mathrm{R}^{2}=0.580, \beta=\right.$ $0.767, p$-value $=0.000)$; therefore, hypothesis $\mathrm{H} 3$ is supported. Next, hypothesis H4, concerning the mediating role job satisfaction plays in the relationship between learning organization and organizational innovation, was examined. Here, the results showed that learning organization indirectly impacts organizational innovation through job satisfaction $\left(\mathrm{R}^{2}=0.680, \beta=0.562, p\right.$-value $=$ $0.000)$; therefore, hypothesis H4 is supported.

\section{Discussion}

This research aimed to investigate whether job satisfaction plays a mediating role in the relationship between learning organization and organizational innovation, which was examined by surveying the employees of insurance companies based in Jordan. A model was developed and examined, which hypothesized that learning organization impacts organizational innovation both directly and indirectly through job satisfaction.

Analyzing the sample using comprehensive methods helped to obtain remarkable information that can be generalized to the entire population. The first and most important finding from the analysis is that there is a strong positive relationship between learning organization and organizational innovation; this finding supports the results of previous studies $[17,19]$.

According to the analysis results, learning organization explains $63.4 \%$ of the variation in organizational innovation. This indicates that insurance companies are operating as learning organizations and depend on this to promote innovation. Since insurance companies operate in a complex and dynamic environment [27], it is likely that they choose to become learning organizations because it is considered a means of coping with environmental changes [98]. There are additional benefits. As mentioned earlier, it has previously been determined that innovation and competitive advantage are achieved when companies follow a learning-organization approach [11]. Furthermore, becoming a learning organization is considered to result in product improvements and better management innovations [83]. In addition, it has been proven that the five disciplines of learning organization are critical in helping employees in promoting organizational innovation [37].

A second finding presented in this analysis indicates that learning organization has a strong positive relationship with job satisfaction. This also supports the results of previous research [22-23].

According to the analysis results, learning organization explains $65.8 \%$ of the variance in job satisfaction. This indicates that employees of insurance companies that operate as learning organizations are highly satisfied. It has been found that employee satisfaction is higher in learning organizations because they are encouraged to be innovative when addressing various challenges [80]. According to [47], learning organization is an excellent strategy for increasing employees' satisfaction levels, and this also helps to retain them in the organization. Employees' satisfaction, 
profitability, and productivity will increase, when their organizations allow and support them to learn and to develop [26].

The third finding of the analysis is that there is a strong positive and significant relationship between job satisfaction and organizational innovation. Again, this finding supports the results of previous studies [24, 99].

Research's results showed that $50.3 \%$ of the variance in organizational innovation is related to job satisfaction. This indicates that insurance companies' innovativeness is dependent on their employees' satisfaction levels, as more effort is put forth when employees are satisfied [24]. In addition, satisfied employees will contribute to improved organizational productivity and innovation [13].

The final finding indicates that job satisfaction plays a mediating role in the relationship between learning organization and organizational innovation. According to the results of the research analysis, learning organization both directly and indirectly impacts organizational innovation through job satisfaction. Specifically, learning organization directly explained $63.4 \%$ of the variance in organizational innovation and indirectly explained $68 \%$ of organizational innovation through job satisfaction. These results show that learning organization accounts for a higher percentage of variance in organizational innovation when job satisfaction acts as a mediator. In other words, insurance companies that operate as learning organizations promote innovativeness [20], particularly when their employees are satisfied with their jobs. This finding suggests that employees in learningorganization settings and with high levels of job satisfaction are more likely to put forth more effort and support their companies' innovativeness [99].

The main contribution of this research is that it is the first empirical research to consider both learning organization and job satisfaction in order to investigate and study organizational innovation. In addition, this research provides sufficient evidence to categorically state that job satisfaction plays a mediating role in the relationship between learning organization and organizational innovation. Therefore, organizations that aim to develop strong innovation capability among their employees should invest more effort in creating a work environment that will boost their employees' job-satisfaction levels [87].

\section{Conclusions, Implications, and Limitations}

\subsection{Conclusions}

This research provides a foundation for investigating the relationship between learning organization and organizational innovation, as well as the mediating role job satisfaction plays in this regard. This was investigated by examining insurance companies in Jordan to determine if they were operating as learning organizations, and if this consequently increased their innovation capabilities and also the satisfaction levels of their employees, which would also help them improve their innovation capabilities.

The research determined that learning organization has a strong positive relationship with organizational innovation. Specifically, the main finding of this research is that, in insurance companies in Jordan, job satisfaction plays a mediating role in the relationship between learning organization and organizational innovation. Thus, to further enhance their innovation, insurance companies must recognize how different components of learning organization can be aligned with employee satisfaction. In other words, insurance companies that are operating as learning organizations should endeavor to increase their employees' satisfaction with regard to their jobs, as satisfied employees can address new challenges and foster creativity, eventually causing their company to be more innovative.

\subsection{Practical Implications}

Insurance companies aspire to provide innovative services, but it is difficult to achieve this goal due to the extremely dynamic and competitive environment in which these companies operate [27]. Thus, insurance companies must invest more effort in and pay more attention to operating as learning organizations and enhancing learning disciplines among their workforces, as this will enable them to further encourage their employees to learn, think critically, and continually adjust to the surrounding environment. Thus, insurance companies should consider the critical role of their employees' job satisfaction in making them more innovative, successful, and competitive.

Insurance companies must not only maintain but also strive to increase their employees' satisfaction levels. This can be achieved through ensuring employees' have a shared vision of company goals (such as by communicating the company vision in a clear way, encouraging them to have common future goals, and by enabling them to participate in the strategic-management process).

\subsection{Limitations and Future Directions}

Since this research concerns insurance companies in Jordan, the findings cannot be generalized to other companies operating in other sectors. An expanded sample size, such as by including all of the insurance companies in the Jordanian insurance sector, would improve the generalizability of the results.

Further, this research recommends conducting more indepth investigations of the relationship between learning organization and organizational innovation, and the mediating role job satisfaction plays in this regard, particularly through the use of different dimensions and perspectives. In addition, this research encourages researchers to conduct similar investigations in various other sectors, such as the banking sector and the industrial sector. 


\section{References}

[1] Chong, A., Chan, F., Ooi, K. and Sim, J. (2011), "Can Malaysian firms improve organizational innovation performance via SCM?", Industrial Management \& Data Systems, Vol. 111 No. 3, pp. 410-431.

[2] Awasthy, R. and Gupta, K. (2012), "Dimensions of the learning organization in an Indian context", International Journal of Emerging Markets, Vol. 7 No. 3, pp. 222-244.

[3] Tsvetkova, A., Thill, J. and Strumsky, D. (2014), "Metropolitan innovation, firm size, and business survival in a high-tech industry", Small Business Economics, Vol. 43 No. 3, pp. 661-676.

[4] Johnston, R. and Bate, J. (2013), The Power of Strategy Innovation: A New Way of Linking Creativity and Strategic Planning to Discover Great Business Opportunities, AMACOM, New York, NY.

[5] Grinsven, M. and Visser, M. (2011), "Empowerment, knowledge conversion and dimensions of organizational learning", The Learning Organization Journal, Vol. 18 No. 5, pp. 378-391.

[6] Eghtesadi, G. and Hamidizadeh, M. (2012), "Organizational learning and organizational innovation”, Kuwait Chapter of Arabian Journal of Business and Management Review, Vol. 1 No. 5, pp. 92-94.

[7] Mendes, M., Gomes, C., Marques-Quinteiro, P., Lind, P. and Curral, L. (2016), "Promoting learning and innovation in organizations through complexity leadership theory", Team Performance Management, Vol. 22 No. 5, pp. 301-309.

[8] Battor, M. and Battor, M. (2010). "The impact of customer relationship management capability on innovation and performance", Journal of Marketing Management, Vol. 26 No. 10, pp. $842-857$.

[9] Sivadas, E. and Dwyer, F. (2000), "An examination of organizational factors influencing new product success in internal and alliance based processes", Journal of Marketing, Vol. 64 No. 1, pp. 31-49.

[10] Bhaskar, U. and Mishra, B. (2017), "Exploring relationship between learning organizations dimensions and organizational performance", International Journal of Emerging Markets, Vol. 12 No. 3, pp. 593-609.

[11] Song, J., Chermack, T. and Kim, W. (2013), "An analysis and synthesis of DLOQ-based learning organization research", Advances in Developing Human Resources, Vol. 15 No. 2, pp. 222-239.

[12] Dizgah, M., Chegini, M., Ferabbod, F. and Kordabadi, S. (2011), "Employee empowerment and organizational effectiveness in the executive organizations", Journal of Basic and Applied Scientific Research, Vol. 1 No. 9, pp. 973-980.

[13] Dobre, O. I. (2013), "Employee motivation and organizational performance", Review of Applied Socio-Economic Research, Vol. 5 No. 1, pp. 53-60.

[14] Sadeghi, V., Jashnsaz, A. and Chobar, M. (2014), "Organization's conformity assessment with Peter Senge's learning organization principles in municipality of Saveh: A case study", Journal of Business and Management, Vol. 16 No. 5, pp. 51-58.
[15] Ries, K. and Trout, N. (1981), "Dimensions of innovation in the hospitality industry", International Journal of Contemporary Hospitality Management, Vol. 9 No. 7, pp. 273-286.

[16] Hatane, S. (2015), "Employee satisfaction and performance as intervening variables of learning organization on financial performance", Procedia-Social and Behavioral Sciences, Vol. 211, pp. 619-628.

[17] Farooq, O. (2012), "Why are some firms more innovative than others? Exploring the role of learning organization components", Global Business and Organizational Excellence, Vol. 31 No. 6, pp. $42-49$.

[18] Burns, T. and Stalker, G. M. (1961), The Management of Innovation, Oxford University Press, Tavistock, UK.

[19] Hussein, N., Mohamad, A., Noordin, F. and Ishak, N. (2014), "Learning organization and its effect on organizational performance and organizational innovativeness: A proposed framework for Malaysian public institutions of higher education", Procedia-Social and Behavioral Sciences, Vol. 130, pp. 299-304.

[20] Park, Y., Hoon Song, J., Won Yoon, S. and Kim, J. (2013), "Learning organization and innovative behavior: The mediating effect of work engagement", European Journal of Training and Development, Vol. 38 No. 1, pp. 75-94.

[21] Kanten, P., Kanten, S. and Gurlek, M. (2015), "The effects of organizational structures and learning organization on job embeddedness and individual adaptive performance", Procedia Economics and Finance, Vol. 23, pp. 1358-1366.

[22] Dekoulou, P. and Trivellas, P. (2015), "Measuring the impact of learning organization on job satisfaction and individual performance in Greek advertising sector", Procedia-Social and Behavioral Sciences, Vol. 175, pp. 367-375.

[23] Erdem, M., Ilgan, A. and Uçar, H. (2014). "Relationship between learning organization and job satisfaction of primary school teachers", International Online Journal of Educational Sciences, Vol. 6 No. 1, pp. 8-20.

[24] Tien, L. and Chao, H. (2012), "Effects of information culture and job satisfaction on the organizational innovation: A study of different leadership styles as a moderatoritle", Advances in Management and Applied Economics Journal, Vol. 2 No. 3, pp. 83-110.

[25] Hussain, H., Talib, N. and Shah, I. (2014), "The impact of intrinsic job satisfaction and extrinsic job satisfaction on product innovation: A case of Iraqi public universities", International Journal of Science and Research, Vol. 3 No. 7, pp. 893-896.

[26] Sabir, H. and Kalyar, M. (2013), "Firm's innovativeness and employee job satisfaction: The role of organizational learning culture", Interdisciplinary Journal of Contemporary Research in Business, Vol. 4 No. 9, pp. 670-686.

[27] Mazloomi, N. and Haghighat, F. (2014), "The relationship between information systems success, organizational learning and performance of insurance companies", International Journal of Business and Social Science, jhonVol. 5 No. 5, pp. 125-132.

[28] Gau, W. and Wen, C. (2011), 'Insurance agencies' organizational learning in a turbulent time: A community of practice perspective", Journal of Modern Education Review, Vol. 1 No. 1, pp. 41-49. 
[29] Abbasi, A., Taqipour, M. and Farhadian, D. (2012), "Learning organization discipline in Iranian higher education system", Journal of Educational and Instructional Studies in the World, Vol. 2 No. 2, pp. 58-68.

[30] Rana, S., Ardichvili, A. and Polesello, D. (2016), "Promoting self-directed learning in a learning organization: Tools and practices", European Journal of Training and Development, Vol. 40 No. 7, pp. 470-489.

[31] Santa, M. (2015), "Learning organization review: A 'good' theory perspective", The Learning Organization, Vol. 22 No. 5 , pp. $242-270$.

[32] Opengart, R. (2015), "Supply chain management and learning organization: A merging of literatures", International Journal of Commerce and Management, Vol. 25 No. 2, pp. 183-195.

[33] Slater, S. and Narver, J. (1995), "Market orientation and the learning organization", Journal of Marketing, Vol. 58 No. 3, pp. 63-74.

[34] Pedler, M., Burgoyne, J. and Boydell, T. (1991), The Learning Company: A Strategy for Sustainable Development, McGrawHill, London.

[35] Garvin, D. A. (2000), Learning in Action: A Guide to Putting the Learning Organization to Work, Harvard Business Press, Boston, MA.

[36] Liao, S., Chang, W. and Wu, C. (2010), “An integrated model for learning organization with strategic view: Benchmarking in the knowledge-intensive industry", Expert Systems with Applications, Vol. 37 No. 5, pp. 3792-3798.

[37] Wen, H. (2014), "The nature, characteristics and ten strategies of learning organization", International Journal of Educational Management, Vol. 28 No. 3, pp. 289-298.

[38] Prugsamatz, R. (2010), "Factors that influence organization learning sustainability in non-profit organizations", The Learning Organization, Vol. 17 No. 3, pp. 243-267.

[39] Nowak, P., Irina, V. and Cseh, M. (2015), "The meaning of organizational learning: A meta-paradigm perspective", Human Resource Development Review, Vol. 14 No. 3, pp. 299-331.

[40] Gil, A. and Mataveli, M. (2017), "Learning opportunities for group learning: An empirical assessment from the learning organization perspective", Journal of Workplace Learning, Vol. 29 No. 1, pp. 65-78.

[41] Shin, H., Picken, J. and Dess, G. (2017), "Revisiting the learning organization", Organizational Dynamics, Vol. 1 No. 46, pp. 46-56.

[42] Senge, P. (1990), The Fifth Discipline: The Art and Science of the Learning Organization, Currency Doubleday, New York, NY.

[43] Kalajahi, M. and Janani, H. (2015), "The effect of the learning organization on empowering physical education teachers in universities of northwest of Iran", Research Journal of Sport Sciences, Vol. 3 No. 6, pp. 149-153.

[44] Čierna, H., Sujová, E., Hąbek, P., Horská, E. and Kapsdorferová, Z. (2017), "Learning organization at higher education institutions in the EU: Proposal for implementing philosophy of learning organization - results from research", Quality \& Quantity, Vol. 51 No. 3, pp. 1305-1320.

[45] Coldwell, D. and Fried, A. (2012), "Learning organizations without borders? A cross-cultural study of university HR practitioners' perceptions of the salience of Senge's five disciplines in effective work outcomes", International Journal of Cross Cultural Management, Vol. 12 No. 1, pp. 101-114.

[46] Ohlsson, J. (2013), "Team learning: Collective reflection processes in teacher teams", Journal of Workplace Learning, Vol. 25 No. 5, pp. 296-309.

[47] Razali, M., Amira, N. and Shobri, N. (2013), "Learning organization practices and job satisfaction among academicians at public university", International Journal of Social Science and Humanity, Vol. 3 No. 6, pp. 518-522.

[48] Yahyagil, M. (2015), "Values, feelings, job satisfaction and well-being: The Turkish case", Management Decision Journal, Vol. 53 No. 10, pp. 2268-2286.

[49] Locke, E. A. (1969), "What is job satisfaction?", Organizational Behavior and Human Performance, Vol. 4, pp. 309-336.

[50] Kianto, A., Vanhala, M. and Heilmann, P. (2016), "The impact of knowledge management on job satisfaction", Journal of Knowledge Management, Vol. 20 No. 4, pp. 621636.

[51] Tarcan, M., Hikmet, N., Schooley, B., Top, M. and Tarcan, G. (2017), "An analysis of the relationship between burnout, socio-demographic and workplace factors and job satisfaction among emergency department health professionals", Applied Nursing Research, Vol. 34, pp. 40-47.

[52] Ollo-López, A., Bayo-Moriones, A. and Larraza-Kintana, M. (2016), "Disentangling the relationship between highinvolvement-work-systems and job satisfaction", Employee Relations, Vol. 38 No. 4, pp. 620-642.

[53] Kiarie, M., Maru, L. and Cheruiyot, T. (2017), "Leader personality traits and employee job satisfaction in the media sector, Kenya", The TQM Journal, Vol. 29 No. 1, pp. 133-146.

[54] Khan, A., Nawaz, M., Aleem, M. and Hamed, W. (2012), "Impact of job satisfaction on employee performance: An empirical study of autonomous medical institutions of Pakistan", African Journal of Business Management, Vol. 6 No. 7, pp. 2697-2705.

[55] Haque, M., Karim, A., Muqtadir, A. and Anam, S. (2012), "Dimensions of job satisfaction of library professionals: A qualitative exploration", International Journal of Business and Social Research, Vol. 2 No. 5, pp. 46-62.

[56] Herzberg, F. (1966), Work and the Nature of Man, World Publishing, Cleveland, $\mathrm{OH}$.

[57] Sardžoska, E. and Tang, T. (2015), "Monetary intelligence: Money attitudes - unethical intentions, intrinsic and extrinsic job satisfaction, and coping strategies across public and private sectors in Macedonia", Journal of Business Ethics, Vol. 130 No. 1, pp. 93-115.

[58] Okan, T. and Akyüz, A. (2015), "Exploring the relationship between ethical leadership and job satisfaction with the mediating role of the level of loyalty to supervisor", Business and Economics Research Journal, Vol. 6 No. 4, pp. 155-177.

[59] Baylor, K. (2010), "The influence of intrinsic and extrinsic job satisfaction factors and affective commitment on the intention to quit for occupations characterized by high voluntary attrition", doctoral dissertation, Nova Southeastern University, available at http://nsuworks.nova.edu/cgi/viewcontent.cgi?article=1009\&co ntext $=$ hsbe etd (accessed 14 December 2017). 
[60] Uzunbacak, H. (2015), "The impacts of employee empowerment on innovation: A survey on Isparta and Burdur organized industrial zones", Journal of International Social Research, Vol. 8 No. 37, pp. 977-989.

[61] Ho, L. (2011), "Meditation, learning, organizational innovation and performance", Industrial Management \& Data Systems, Vol. 111 No. 1, pp. 113-131.

[62] Martin-Rios, C. (2016), "Sense-making of organizational innovation and change in public research organizations", International Journal of Organizational Analysis, Vol. 24 No. 3 , pp. 516-531.

[63] Jiménez-Jiménez, D. and Sanz-Valle, R. (2011), "Innovation, organizational learning, and performance", Journal of Business Research, Vol. 64 No. 4, pp. 408-417.

[64] Dixon, S., Meyer, K. and Day, M. (2014), "Building dynamic capabilities of adaptation and innovation: A study of microfoundations in transition economy", Long Range Planning, Vol. 47 No. 4, pp. 186-205.

[65] Fu, N., Flood, P., Bosak, J., Morris, T. and O'Regan, P. (2015), "How do high performance work systems influence organizational innovation in professional service firms?", Employee Relations, Vol. 37 No. 2, pp. 209-231.

[66] Damanpour, F. (1991), "Organizational innovation: A metaanalysis of effects of determinants and moderators", Academy of Management Journal, Vol. 34 No. 3, pp. 555-590.

[67] Bas, C., Mothe, C. and Nguyen-Thi, T. U. (2015), "The differentiated impacts of organizational innovation practices on technological innovation persistence", European Journal of Innovation Management, Vol. 18 No. 1, pp. 110-127.

[68] Baragde, D. and Baporikar, N. (2017), "Business innovation in Indian software industries", Journal of Science and Technology Policy Management, Vol. 8 No. 1, pp. 62-75.

[69] Laforet, S. (2011). "A framework of organizational innovation and outcomes in SMEs", International Journal of Entrepreneurial Behavior and Research, Vol. 17 No. 4, pp. 380-408.

[70] Damanpour, F. and Aravind, D. (2012), "Managerial innovation: Conceptions, processes, and antecedents", Management and Organization Review, Vol. 8 No. 2, pp. 423-454.

[71] Battisti, G. and Stoneman, P. (2010), "How innovative are UK firms? Evidence from the fourth UK community innovation survey on synergies between technological and organizational innovations", British Journal of Management, Vol. 21 No. 1, pp. 187-206.

[72] Mafabi, S., Munene, J. and Ntayi, J. (2012), "Knowledge management and organizational resilience: Organizational innovation as a mediator in Uganda parastatals", Journal of Strategy and Management, Vol. 5 No. 1, pp. 57-80.

[73] Wang, C. L. and Ahmed, P. K. (2004), "The development and validation of the organizational innovativeness construct using confirmatory factor analysis", European Journal of Innovation Management, Vol. 7 No. 4, pp. 303-13.

[74] OECD. (2005), Oslo Manual: Guidelines for Collecting and Interpreting Innovation Data, OECD Publishing, Paris.

[75] Christensen, K. (2006), "Losing innovation: The challenge of being acquired”, Management Decision, Vol. 44 No. 9, pp. 1161-82.
[76] Riivari, E., Lämsä, A., Kujala, J. and Heiskanen, E. (2012), "The ethical culture of organizations and organizational innovativeness", European Journal of Innovation Management, Vol. 15 No. 3, pp. 310-331.

[77] Ali, M., Kan, K. and Sarstedt, M. (2016), "Direct and configurational paths of absorptive capacity and organizational innovation to successful organizational performance", Journal of Business Research, Vol. 69 No. 11, pp. 5317-5323.

[78] Liao, S., Fei, W. and Chen, C. (2007), "Knowledge sharing, absorptive capacity and innovation capability: An empirical study of Taiwan's knowledge-intensive industries", Journal of Information Science, Vol. 33 No. 3, pp. 340-359.

[79] Chang, S. and Lee, M. (2007), "A study on relationships among leadership, organizational culture, the operation of learning organization and employees' job satisfaction", The Learning Organization, Vol. 14 No. 2, pp. 155-185.

[80] Singh, E. (2016), "Learning organization and its impact on organizational effectiveness: A literature review", International Journal of Research in Commerce \& Management, Vol. 7 No. 6, pp. 37-39.

[81] Laeeque, S. and Babar, S. (2015), "Learning organization as a strategy to improve performance of Pakistani hospitals", Journal of Managerial Sciences, Vol. 12 No. 2, pp. 255-265.

[82] Hyjek, A. (2014), "A learning public organization as the condition for innovations adaptation", Procedia-Social and Behavioral Sciences, Vol. 110, pp. 148-155.

[83] S`kerlavaj, M., Song, J. H. and Lee, Y. (2010), "Organizational learning culture, innovative culture and innovations in South Korean firms", Expert Systems with Applications, Vol. 37 No. 9, pp. 6390-6403.

[84] Chen, X., Zhao, K., Liu, X. and Dash Wu, D. (2012), "Improving employees' job satisfaction and innovation performance using conflict management", International Journal of Conflict Management, Vol. 23 No. 2, pp. 151-172.

[85] Lambert, E., Hogan, N., Jiang, S., Jiang, S., Elechi, O., Benjamin, B., Morris, A., Laux, J. and Dupuy, P. (2010), "The relationship among distributive and procedural justice and correctional life satisfaction, burnout, and turnover intent: An exploratory study", Journal of Criminal Justice, Vol. 38 No. 1, pp. 7-16.

[86] Shipton, H., West, M., Parkes, C., Dawson, J. and Patterson, M. (2006), "When promoting positive feelings pays: Aggregate job satisfaction, work design features, and innovation in manufacturing organizations", European Journal of Work and Organizational Psychology, Vol. 15 No. 4, pp. 404-430.

[87] Kurland, H. and Hasson-Gilad, D. (2015), "Organizational learning and extra effort: The mediating effect of job satisfaction", Teaching and Teacher Education, Vol. 49, pp. 56-67.

[88] Sekaran, U. and Bougie, R. (2016), Research Methods for Business: A Skill Building Approach, 7th ed., Wiley, Hoboken, NJ.

[89] Al-Qutop, M., Moh'd Futa, S. and Ma'ani, A. (2011), “The relationship between learning facilitators and transforming into a learning organization: An empirical study of the insurance sector in Jordan", International Business Research, Vol. 4 No. 3, pp. 211-220. 
[90] Weiss, D., England, G. and Lofquist, L. (1967), Manual for the Minnesota Satisfaction Questionnaire (Minnesota Studies in Vocational Rehabilitation), Vol. 22., University of Minnesota Press, Minneapolis, MN.

[91] Thompson, B. (2004), Exploratory and Confirmatory Factor Analysis: Understanding Concepts and Applications, American Psychological Association, Washington, DC.

[92] Williams, M., Grajales, C. and Kurkiewicz, D. (2013), "Assumptions of multiple regression: Correcting two misconceptions", Practical Assessment, Research and Evaluation, Vol. 18 No. 11, pp. 1-14.

[93] Hair, F., Black, C., Babin, J., Anderson, E. and Tatham, L. (2010), Multivariate Data Analysis, 7th ed., Macmillan, New York.

[94] Yilmaz, K. (2013), "Comparison of quantitative and qualitative research traditions: Epistemological, theoretical, and methodological differences", European Journal of Education, Vol. 48 No. 2, pp. 311-325.
[95] Connelly, L. (2011), "Research roundtable. Cronbach's alpha", Medsurg Nursing, Vol. 20 No. 1, p. 45.

[96] Nunnally, J. C. (1978), Psychometric Theory, 2nd ed., McGraw-Hill, New York.

[97] Baron, R. and Kenny, D. (1986), "Moderator mediator variables distinction in social psychological research: Conceptual, strategic, and statistical considerations", Journal of Personality and Social Psychology, Vol. 51 No. 6, pp. 1173-1182.

[98] Hung, R., Yang, B., Lien, B., McLean, G. and Kuo, Y (2010), "Dynamic capability: Impact of process alignment and organizational learning culture on performance", Journal of World Business, Vol. 5 No. 3, pp. 285-294.

[99] Ayala, Y., Silla, J., Tordera, N., Lorente, L. and Yeves, J. (2017), "Job satisfaction and innovative performance in young Spanish employees: Testing new patterns in the happyproductive worker thesis-A discriminant study", Journal of Happiness Studies, Vol. 18, pp. 1-25. 